\title{
IDENTIFIKASI STAKEHOLDER PENGELOLAAN PEMANFAATAN JASA EKOSISTEM DI TAMAN NASIONAL BALURAN
}

\author{
Identify of Stakeholders of Utilization Ecosystem Services Management in \\ Baluran National Park
}

\author{
Joko Mulyo Ichtiarso
}

Staf Taman Nasional Baluran, Jawa Timur

\section{Diterima 15 September 2018/Disetujui 10 Oktober 2018}

\begin{abstract}
Baluran National Park has an ecosystem service that's used directly by the people of buffer village. The amount of benefits from these ecosystem services has not received attention in management activities in Baluran National Park. The last 5 years data on the number of tourist visits reached 176,888 tourists, namely 172,039 domestic tourists and 4,849 foreign tourists. However, villagers only play a role in providing tourist motorcycle taxi services. So that people have access to the use of ecosystem services. The purpose of this research is to identify of stakeholders of utilization ecosystem services management in Baluran National Park. The method of research uses quantitative and qualitative approaches, purposive sampling, and interviews using questionnaires. The Analyze is qualitative descriptions and analysis of policy contents. The result of this study is describe of stakeholders of utilization ecosystem service management in Baluran National Park accommodates various interests of stakeholders who can be involved in the management of the use of Baluran National Park ecosystem services.
\end{abstract}

Keywords: Management, Utilization Ecosystem Services, Baluran National Park

\section{PENDAHULUAN}

Taman Nasional Baluran (TNB) merupakan salah satu dari 5 (lima) taman nasional pertama yang ditunjuk dan diresmikan oleh pemerintah Indonesia pada tanggal 6 Maret 1980 melalui Surat Keputusan Menteri Pertanian pada tanggal 6 Maret 1980. Sebelum ditunjuk sebagai taman nasional, Baluran merupakan kawasan Suaka Margasatwa (SM) yang kawasannya meliputi wilayah 
Pegunungan Ijen dan Alas Purwo. Berdasarkan Surat Keputusan Menteri Kehutanan Nomor : 279/Kpts-IV/1997 tanggal 23 Mei 1997, Baluran ditunjuk sebagai Taman Nasional tersendiri dengan luas 25.000 Ha terpisah dari wilayah Pengunungan Ijen dan Alas Purwo.

Jenis jasa ekositem yang dimanfaatkan oleh masayarakat sekitar TNB diantaranya: hasil hutan bukan kayu (HHBK), rekreasi, dan siklus nutrient (ketersediaan karbon). HHBK di Taman Nasional Baluran terdapat sebanyak 10 jenis yang telah dimanfaatkan oleh masyarakat desa penyangga (TN Baluran 2014). Masyarakat seakan tidak mempedulikan informasi dan peraturan yang ada di TN Baluran terkait pemanfaatan jasa ekosistem ini.

Pengambilan HHBK yang seharus nya hanya di zona pemanfaatan dan tradisional atau pemanfaatan khusus saja, pada kenyataanya sudah terlampau masuk ke semua zona bahkan di zona inti. Padahal kegiatan pemanfaatan jasa ekosistem yang didalam nya termasuk HHBK di kawasan taman nasional hanya diperbolehkan di zona pemanfaatan, tradisional dan khusus, sementara zona inti dan rimba mutlak tidak diizinkan (Kemenhut 2006).

Ketergantungan masyarakat desa penyangga sekitar kawasan TNB terhadap jasa ekosistem hutan masih tinggi. Sebagian masyarakat desa penyangga TNB sudah memanfaatkan dan/atau mendapatkan nilai atau value jasa ekosistem TNB, khususnya HHBK dan manfaat dari kegiatan wisata di TNB. Dengan demikian, dapat dikatakan bahwa jasa ekosistem tersebut mempunyai nilai ekonomi bagi masyarakat sekitar kawasan TN Baluran.

Pengelolaan pemanfaatan jasa ekosistem di TNB sejauh ini masih belum berjalan dengan optimal. Terlebih lagi terkait pengelolaan pemanfaatan jasa ekosistem berupa HHBK yang dimanfaatkan oleh masyarakat sekitar desa penyangganya. Kegiatan masyarakat untuk mengambil atau memungut jasa ekositem berupa HHBK sudah berlangsung sejak tahun 1960-an, jauh sebelum adanya penunjukan kawasan menjadi taman nasional.

Pendekatan pemanfaatan jasa ekosistem di TNB ini erat kaitannya dengan hak atau akses masyarakat desa penyangga. Hak pemanfaatan jasa ekosistem oleh masyarakat desa penyangga tersebut masih dinilai sangat terbatas, sedangkan pada ruang kebijakan sudah terdapat regulasi yang jelas. Atas dasar fenomena tersebut, maka dirasa perlu dilakukan kegiatan penelitian terkait identifikasi stakeholder pengelolaan pemanfaatan jasa ekosistem di TNB yang sesuai dengan ruang kebijakan yang sudah ada. 


\section{METODE PENELITIAN}

Penelitian dilakukan di Kawasan TNB dan desa penyangga TNB serta lingkup pemerintahan daerah setempat (Situbondo). Waktu penelitian dilakukan pada bulan Januari hingga Februari 2017. Pengambilan data dilakukan dengan observasi langsung dan penyebaran kuisioner kepada stakeholder terlibat melalui wawancara mendalam (in depth interview) dengan para aktor pengambil kebijakan dari pengelola TNB dan stakeholder. Pemilihan responden dan informan dilakukan secara purposive sampling yang disesuaikan dengan pengetahuan dan pengalaman informan kunci sesuai masalah yang akan dikaji, dan informan kunci dianggap dapat menjawab tujuan penelitian.

Analisis data mengenai stakeholders menggunakan analisis stakeholder (Reed et al. 2009) yang meliputi 3 langkah ialah (1) mengidentifikasi stakeholder, (2) membedakan antara dan mengelompokkan stakeholder, serta (3) menyelidiki hubungan antar stakeholder. Setelah stakeholder teridentifikasi, langkah selanjutnya adalah mengkaji kepentingan (importance) dan pengaruhnya (influence). Setelah kepentingan dan pengaruh stakeholder diketahui, maka langkah berikutnya adalah membedakan antara dan atau mengelompokkan stakeholder berdasarkan posisinya terkait nilai kepentingan dan pengaruhnya dalam pengelolaan pemanfaatan jasa ekosistem di TNB menggunakan matriks kepentingan-pengaruh atau interest-influence matriks dan skoring.

\section{HASIL DAN PEMBAHASAN}

\section{Stakeholder Pengelolaan Pemanfaatan Jasa Ekosistem TNB}

Pengelolaan pemanfaatan jasa ekosistem TNB masih belum berjalan dengan baik. Pemanfaatan jasa ekosistem TNB oleh masyarakat desa penyangga terus berlangsung dengan tanpa adanya regulasi maupun kelembagaan yang jelas. Masyarakat memanfaatkan jasa ekosistem TNB secara tradisional dan belum mendapatkan perhatian dari pihak pengelola TNB. Pihak pengelola kawasan hanya melakukan kegiatan pengawasan (monitoring) terhadap masyarakat pemanfaat jasa ekosistem yang keluar masuk kawasan setiap harinya. Pengelola belum merumuskan aturan main (kelembagaan) yang jelas dalam rangka pemanfaatan jasa ekosistem TNB.

Hasil penelitian ini menunjukkan bahwa kelembagaan pengelolaan pemanfaatan jasa ekosistem TNB belum terbentuk, tetapi faktanya sudah ada komunikasi dengan para pihak (stakeholder) disekitar TNB. Hal ini menjadi 
peluang untuk meningkatkan efektifitas kegiatan pengelolaan pemanfaatan jasa ekosistem TNB. Para pihak yang dapat dijadikan sebagai mitra atau stakeholder pengelolaan pemanfaatan jasa ekosistem TNB masih terkoordinir menjadi suatu kelembagaan pengelolaan manfaatan jasa ekosistem TNB. Menurut Freeman (1984) stakeholder didefinisikan sebagai berbagai pihak dari suatu organisasi yang dapat mempengaruhi atau dipengaruhi (menerima dampak) dari sebuah keputusan yang telah diambil secara bersama dengan tanpa merugikan salah satu pihak. Dapat difenisikan pula sebagai individu, orang, kelompok atau organisasi yang memiliki perhatian dan/atau dapat mempengaruhi hasil dari suatu kegiatan (Kusumedi dan Bisjoe, 2010). Stakeholder yang dapat mendukung pengelolaan pemanfaatan jasa ekosistem TNB seperti dalam Tabel 2.

Tabel 2. Identifikasi stakeholder pengelolaan pemanfaatan jasa ekosistem TNB

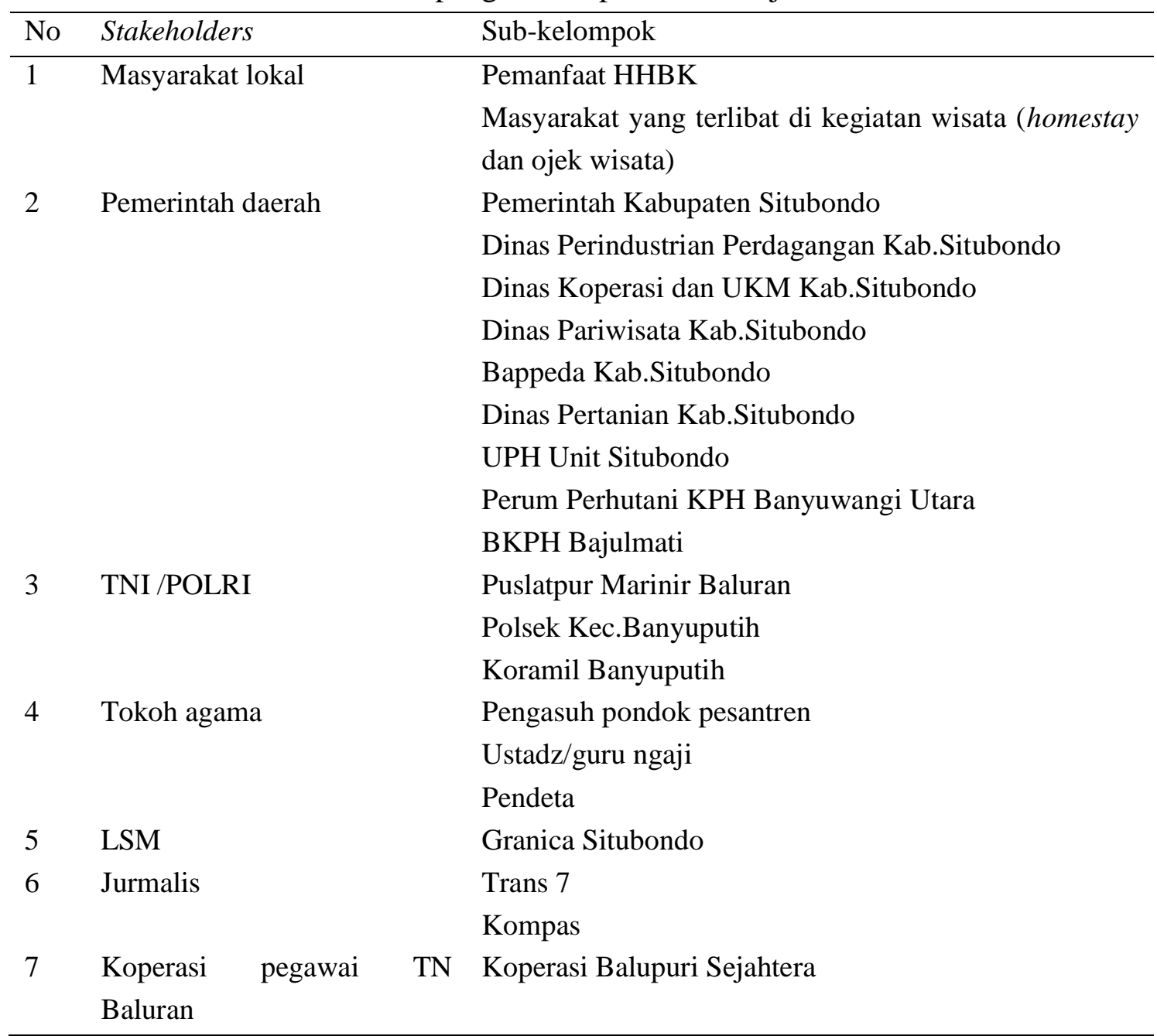

Sumber : data primer 2018 
Tabel 2 menunjukkan terdapat tujuh stakeholder utama yang dianggap potensial atau yang sudah terlibat dengan pengelolaan pemanfaatan jasa ekosistem TNB. Keterlibatan stakeholder secara langsung dalam pengelolaan pemanfaatan jasa ekosistem TNB saat ini masih belum terjadi, hal ini dikarenakan pengaruh pengelolaan taman nasional yang masih cenderung bersifat sentralistik dan belum sepenuhnya menjalankan desentralisasi pengelolaan, sehingga pihak TNB masih berfungsi sebagai pemilik atau penguasa (owner) yang mempunyai kewenangan mutlak dalam hal terkait property rights (access, withdrawal, management, exclusion, dan alienation). Aturan dalam mengelola kawasan hutan di Indonesia masih bersifat sentralistik, artinya hak pembuatan aturan pada semua tingkatan yaitu tingkat operasional, pilihan kolektif, dan konstitusi menjadi kewenangan pemerintah pusat (Nopiansyah 2016).

Masyarakat lokal memanfaatkan HHBK di TNB dan terlibat dalam kegiatan wisata TNB seperti penyedia homestay dan jasa transportasi ojeg wisata. Selama ini masyarakat masih belum dilibatkan secara aktif dan partisipatif di dalam setiap pengambilan keputusan baik secara kolektif (collective choice level) pada tingkat kebijakan maupun pada tingkat operasional (operational choice level). Masyarakat pemanfaat jasa ekosistem TNB hanya dijadikan sebagai pihak yang tidak berdaya guna dan sebagai penerima segala bentuk kebijakan yang sudah ada di lingkup pengelola kawasan. Masyarakat sekitar kawasan taman nasional di Indonesia seringkali diposisikan sebagai objek pengelolaan kawasan dan tidak pernah dilibatkan sebagai subyek dalam pengambilan keputusan atau kebijakan walaupun kebijakan tersebut diperuntukkan kepada mereka (Roslinda et al. 2012).

Pemerintah Kab.Situbondo secara herirarki masih mendapatkan pengaruh dari pemerintah provinsi dalam hal regulasi pemerintahannya. Adapun instansi yang termasuk ke dalam kategori pemerintah daerah yaitu: pemerintah Kab.Situbondo dan beberapa dinas terkait (pariwisata, UMKM, perindustrian, koperasi, bappeda, dan pertanian), Perum Perhutani KPH Banyuwangi Utara, unit pengelola hutan wilayah (UPHW) Situbondo. Kawasan TNB sebelah barat berbatasan langsung dengan komplek pusat latihan tempur (Puslatpur) Marinir Karangtekok. Keberadaan lembaga militer ini harus dijadikan sebagai peluang untuk membangun kegiatan bersama dalam kontek kolaborasi. Hasil penelitian menunjukkan bahwa belum adanya kerjasama antara TNB dengan Puslatpur Marinir tersebut,sehingga kegiatan pengelolaan TNB masih bersifat berdiri sendiri (single authority). Demikian juga dengan keberadaan Koramil Kecamatan Banyuputih dan Polsek Kecamatan Banyuputih. Ketiga lembaga tersebut sejauh 
ini masih dilibatkan hanya sebatas kegiatan pengamanan kawasan TNB dari tindak pelanggaran hutan saja.

Pelibatan tokoh agama dalam pengelolaan pemanfaatan jasa ekosistem TNB berdasarkan hasil penelitian ini masih belum terlaksana. Tokoh agama yang ada di desa penyangga TNB terdiri dari kyai pengasuh pondok pesantren, ustadz yang mengajar ngaji, dan pendeta di beberapa gereja Desa Wonorejo dan Desa Sumberwaru. Selama ini para tokoh agama belum pernah dijadikan sebagai subyek dalam kegiatan pengelolaan kawasan TNB terlebih dalam kegaitan pemanfaatan jasa ekosistem TNB. Kultur masyarakat desa penyangga TNB yang didominasi oleh etnis Madura dan Jawa ini sangat menghormati dan mentaati ulama atau kyai setempat melebihi rasa hormat dan mentaati pemerintah ataupun aparat hukum yang lain ${ }^{1}$.

Lembaga Swadaya Masyarakat (LSM) Granica Situbondo merupakan organisasi yang berawal dari kegiatan komunitas pelajar pecinta alam yang berasal dari Situbondo sejak tahun 1990-an. Kemudian komunitas ini seringkali melakukan kegiatan pendidikan konservasi di kawasan TNB bahkan pendampingan kepada masyarakat sekitar kawasan hutan TNB. Komunikasi antara pihak TNB dengan lembaga ini cukup intens terlabih sering dilibatkan dalam kegiatan bina cinta alam TNB yang berlatar belakang pendidikan konservasi.

Jurnalis merupakan stakeholder yang tidak bida dipisahkan dalam kegiatan pengelolaan pemanfaatan jasa ekosistem TNB. Jurnalis atau media massa bisa menjadi stakeholder yang potensial untuk mendukung pengelolaan dalam kapasitasnya sebagai aktor yang mendukung kegiatan penyebaran informasi tentang TNB kepada masyarakat secara luas.

Kepentingan dan pengaruh stakeholder akan selalu berubah sesuai dengan dinamika berbagai parameter penyusunnya. Hal ini sesuai dengan pendapat Reed et al. (2009) bahwa kepentingan dan pengaruh stakeholder dapat berubah sepanjang waktu, dan dampak perubahan tersebut perlu dijadikan pertimbangan bagi pengelola suatu kawasan. Sesuai dengan kebutuhan dan perkembangan saat ini, pengelolaan suatu CBPS mutlak ditangani multi stakeholders yang dapat dibangun melalui suatu kemitraan.

\section{Kategorisasi Stakeholder}

Tingkat kepentingan dan pengaruh stakeholder dapat terpetakan setelah melihat skoring terhadap masing-masing parameter kepentingan (de Groot et.al

\footnotetext{
${ }^{1}$ Pengasuh PP Salafiyah Syafi'iyah Situbondo
} 
2002) dan pengaruh sesuai dengan Groenendijk (2003) seperti pada Tabel 2. Jumlah stakeholder yang mempunyai kepentingan dan pengaruh dalam pengelolaan jasa ekosistem TNB pada saat ini sebanyak delapan actor dengan tingkatan kepentingan dan pengaruh yang berbeda-beda (Tabel 3).

Tingkat kepentingan yang mengacu pada de Groot et al. (2002) terdapat lima tipe kepentingan, yaitu: pengaturan atau regulasi, habitat, produksi, informasi, dan carrier. Sedangkan tingkat pengaruh mengacu pada Groenendijk (2003), yaitu: pengaruh stakeholder yang mampu memberikan hukuman atau sanksi yang sepadan kepada stakeholder lain (condign power), pengaruh yang diperoleh melalui kemampuan dalam memberi kompensasi bagi stakeholder lainnya (compensatory power), pengaruh yang diperoleh melalui menipulasi kepercayaan atau pembentukan opini dan informasi (conditioning power), pengaruh yang diperoleh karena aspek kepribadian (personality power), dan pengaruh yang diperoleh dari organisasi yang mempunyai kesesuaian bidang tugas, jejaring, sistem yang baik, dan kontribusi terhadap fasilitas (organization power). Pengaruh stakeholders terhadap pengelolaan SDA diukur berdasarkan instrumen dan sumber kekuatannya, sebagaimana yang disebutkan oleh Galbraith (1983) dalam Reed et al. (2009).

Tabel 3. Tabel hubungan stakeholder berdasar tingkat kepentingan dan pengaruh

\begin{tabular}{|c|c|c|c|c|c|c|c|c|c|c|c|c|}
\hline \multirow{2}{*}{ Stakeholders } & \multicolumn{6}{|c|}{ Kepentingan } & \multicolumn{6}{|c|}{ Pengaruh } \\
\hline & 1 & 2 & 3 & 4 & 5 & Skor & 6 & 7 & 8 & 0 & 11 & Skor \\
\hline Masyarakat HHBK & 2 & 2 & 5 & 4 & 4 & 3,40 & 1 & 1 & 4 & 1 & 1 & 1,33 \\
\hline Masyarakat Wisata & 2 & 2 & 2 & 2 & 5 & 2,60 & 1 & 1 & 4 & 1 & 1 & 1,33 \\
\hline Pemerintah Daerah & 4 & 4 & 3 & 3 & 5 & 3,80 & 4 & 4 & 4 & 5 & 5 & 3,67 \\
\hline TNI /POLRI & 4 & 4 & 1 & 1 & 4 & 2,20 & 5 & 4 & 2 & 3 & 4 & 3,00 \\
\hline Tokoh Agama & 4 & 4 & 1 & 1 & 1 & 2,20 & 2 & 2 & 5 & 5 & 5 & 3,17 \\
\hline LSM & 3 & 3 & 1 & 1 & 3 & 2,20 & 2 & 1 & 5 & 4 & 5 & 3,00 \\
\hline Jurnalis & 2 & 2 & 1 & 4 & 1 & 2,00 & 4 & 4 & 5 & 5 & 5 & 3,83 \\
\hline Koperasi Pegawai & 4 & 4 & 1 & 1 & 1 & 2,20 & 1 & 1 & 2 & 1 & 5 & 1,67 \\
\hline
\end{tabular}

${ }^{\mathrm{a}}$ Kepentingan dan pengaruh stakeholders; 1: pengaturan, 2: habitat, 3: produksi, 4: informasi, 5: carrier, 6: condign power, 7: compensatory power, 8: conditioning power, 9: personality power dan property power, 10: organization power.

Penentuan stakeholders yang perlu diajak bekerja sama dalam pengelolaan pemanfaatan jasa ekosistem TNB dikelompokkan berdasarkan pengaruh dan kepentingan spesifik yang dimilikinya (Reed et al. 2009). Stakeholders yang masuk kategori key players, subjects, dan context setters merupakan stakeholders 
inti yang perlu diperhatikan untuk mencapai keberhasilan suatu program atau kegiatan secara bersama-sama (Groenendijk 2003). Berdasarkan kategorisasi atas kepentingan dan pengaruh stakeholder dalam pengelolaan pemanfaatan jasa ekosistem TNB dihasilkan empat kuadran (Gambar 1).

Kuadran I disebut sebagai Subjects, yaitu stakeholder yang memiliki tingkat kepentingan tinggi tetapi pengaruhnya rendah dalam pengelolaan pemanfaatan jasa ekosistem TNB. Stakeholders yang termasuk kategori subjects meliputi: masyarakat HHBK dan masyarakat wisata. Masyarakat sekitar kawasan hutan harus mendapatkan manfaat sebesar-besarnya dari keberadaan taman nasional (Soekmadi 2002). Masyarakat yang memanfaatkan HHBK di TNB mempunyai tingkat kepetingan yang tinggi. Masyarakat HHBK setiap hari dan setiap musim panen raya selalu memanfaatkan jasa ekosistem TNB secara perorangan maupun kelompok. Masyarakat tersebut mempunyai lima kepentingan sesuai de Groot et al. (2002), yaitu: pengaturan, fungsi pengaturan atau regulasi, fungsi habitat, fungsi produksi, fungsi informasi, dan fungsi carrier. Kepentingan yang tinggi dari masyarakat terhadap SDA terutama berkenaan dengan fungsi jasa ekosistem dari TNB. Hal ini disebabkan masyarakat sekitar hutan TNB masih berada pada tingkat perekonomian yang rendah, yaitu masih menggantungkan hidup dari hutan TNB (BTNB 2014).

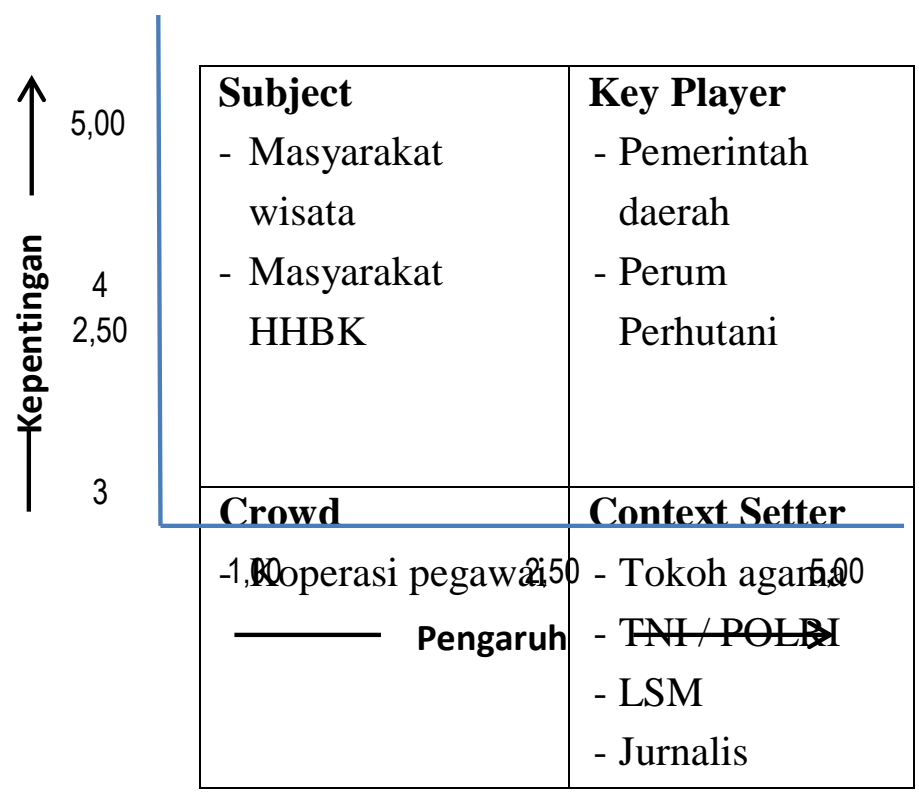

Gambar 1. Klasifikasi stakeholder pengelolaan jasa ekosistem TNB 
Masyarakat wisata TNB merupakan masyarakat sekitar hutan TNB yang telah merasakan manfaat dari kegiatan wisata di TNB. Masyarakat wisata terbagi ke dalam dua kelompok, yaitu masyarakat sebagai jasa transportasi/ojeg wisata dan penyedia tempat penginapan (homestay) di desa penyangga TNB. Masyarakat wisata ini mempunyai tingkat kepentingan tinggi terhadap jasa ekosistem TNB terutama pada fungsi informasi dan fungsi carrier.

Kepentingan yang dimiliki masyarakat TNB tinggi, sedangkan pengaruhnya sangat rendah. Hal ini disebabkan masyarakat desa penyangga TNB tidak mempunyai instrumen dan sumber kekuatan yang melekat pada mereka. Pengaruh yang kurang tinggi ini disebabkan oleh tingkat kemampuan masyarakat dalam mempengaruhi pihak lain, memberikan kompensasi bagi perilaku yang baik, dan menggerakkan massa untuk mendukung kegiatan pengelolaan pemanfaatan jasa ekosistem TNB. Masyarakat mempunyai jejaring yang kecil sehingga belum bisa memberikan pengaruh yang tinggi kepada masyarakat yang lain.

Masyarakat tidak mempunyai hak atau akses untuk memberikan pengaruh terhadap pengelolaan TNB, padahal masyarakat seharusnya diberikan kewenangan atau terlibat di dalam kegiatan pengelolaan bukan hanya sekedar dijadikan sebagai objek kegiatan pengelolaan pemanfaatan jasa ekosistem. Hampir disebagian besar pengelolaan kawasan taman nasional Indonesia memposisikan masyarakat di sekitar kawasan sebagai objek kegiatan pengelolaan (Rosalinda et.al 2012), sehingga masyarakat sekitar hutan tidak pernah diberikan kesempatan untuk berkontribusi dalam pengelolaan pemanfaatan jasa ekosistem TNB.

Kuadran II disebut sebagai Key players adalah stakeholder yang aktif dan kritis karena memiliki tingkat kepentingan tinggi dan pengaruh yang tinggi terhadap implementsi pengelolaan pemanfaatan jasa ekosistem TNB. Key players memiliki kapasitas sumber daya yang besar, baik sumber daya manusia maupun fasilitas, finansial, anggaran, sistem organisasi, data dan informasi yang mendukung kekuatan atau pengaruh terhadap jasa ekosistem TNB. Stakeholder yang termasuk key players adalah Pemerintah daerah, yaitu pemerintah Kabupaten Situbondo beserta dinas yang terkait, Perum Perhutani, dan Unit Pengelola Hutan Situbondo yang merupakan kepanjangan tangan dari pemerintah provinsi Jawa Timur.

Pemerintah Kabupaten Situbondo, Badan perencanaan pembangunan daerah (BAPPEDA), Dinas perindustrian dan perdagangan, Dinas UKM, Dinas Pariwisata, dan Dinas Pertanian Kabupaten Situbondo mempunyai kepentingan besar terhadap jasa ekosistem TNB. Jasa ekosistem TN dalam bentuk pengaturan 
sistem penyangga kehidupan, pendukung kehidupan yang bermanfaat, penjaga ketersediaan air bersih bagi masyarakat Situbondo, pelindung tanah dari erosi, dan menjaga stabilitas kualitas udara. Keutuhan jasa ekosistem TNB sangat dibutuhkan oleh pemerintah Kabupaten Situbondo untuk memenuhi kebutuhan ruang hijau. Kepentingan berupa penyedia berbagai macam bahan baku dan pangan serta sumber energi berupa cadangan karbon dan kayu bakar bagi pemerintah daerah menjadi keniscayaan untuk turut dalam mempertahankan keberadaan pengelolaan jasa ekosistem TNB. Pemerintah Kabupaten Situbondo juga sangat mendorong pengembangan aspek wisata di TNB, yaitu pembangunan wisata alam Situbondo dengan mendorong pengelolaan wisata di TNB. Hal ini menunjukkan bahwa Pemerintah Daerah Situbondo mempunyai lima kepentingan menurut de Groot et.al. (2002), yaitu: fungsi pengaturan atau regulasi, fungsi habitat, fungsi produksi, fungsi informasi, dan fungsi carrier. Namun, belum terbentuknya sebuah mekanisme pengelolaan pemanfaatan jasa ekosistem TNB, kepentingan pemerintah daerah tersebut masih belum tampak.

Pemerintah daerah mempunyai pengaruh yang tinggi di dalam pengelolaan pemanfaatan jasa ekosistem TNB. Pemerintah Daerah Situbondo mempunyai instrument kekuatan dan sumber kekuatan yang besar. Keberadaan TNB yang secara administrartif masuk dalam wilayah hukum Kabupaten Situbondo menjadi instrument kekuatan bagi pemerintah daerah Situbondo. Pemerintah daerah mempunyai tiga instrument kekuatan menurut Galbraith (1983) dalam Reed et al. (2009), yaitu: condign power, compensatory power, dan conditioning power. Sumber kekuatan menurut Galbraith (1983) dalam Reed et al. (2009), yaitu Bupati Situbondo mempunyai kekuatan untuk mendorong dan menggerakkan berbagai instansi pemerintahan hingga tingkat pemerintahan kecamatan dan desa di sekitar TNB.

Kuadran III disebut sebagai Context setters adalah stakeholder yang memiliki kepentingan rendah tetapi pengaruhnya tinggi sehingga dapat memberi manfaat atau risiko yang signifikan dalam menjembatani opini dan pengambilan keputusan. Stakeholder yang termasuk sebagai context setters, yaitu tokoh agama, TNI/POLRI, LSM, dan jurnalis atau media masa. Beberapa aktor tersebut tidak mempunyai kepentingan yang besar terhadap jasa ekosistem TNB. Kepentingan mereka terhadap jasa ekosistem TNB hanya sebatas pada kepentingan pada fungsi pengaturan, habitat, dan informasi.

Pengaruh yang dimiliki oleh tokoh agama disekitar TNB sangat besar. Sumber kekuatan berupa kemampuan memimpin umat atau jamaah menjadikan tokoh agama ini dengan mudah dapat menggerakkan masyarakat dan 
mempengaruhi pola pemikiran masyarakat sekitar TNB (personality power). Tokoh agama di sekitar TNB terdiri dari dua tokoh, yaitu tokoh pengasuh pondok pesantren (islam) dan tokoh pemimpin gereja-gereja (kristen). Kedua tokoh agama tersebut mempunyai jaringan masa yang sangat besar di desa penyangga TNB (organization power).

TNI/POLRI di sekitar kawasan TNB, yaitu Koramil, Polsek, dan Puslatpur Marinir Karangtekok. Ketiga instansi militer ini mempunyai pengaruh dalam hal pemberian hukum atau sanksi yang sepadan kepada stakeholder yang lain (condign power), aturan main, dan kompensasi terhadap para pihak yang berkaitan (compensatory power). TNI/POLRI sejauh ini sudah menjadi mitra dalam bidang pengamanan kawasan hutan dari ancaman gangguan tindak pelanggaran hukum kehutanan.

LSM dan Jurnalis mempunyai pengaruh yang tinggi dalam pengelolaan pemanfaatan jasa ekosistem TNB. Pengaruh dalam hal pembangunan opini dan pengumpulan informasi terkait pemanfaatan jasa ekosistem untuk disebarluaskan kepada masyarkat umum (conditioning power). LSM juga berperan sebagai pendamping pengelola TNB dalam bentuk berbagai kegiatan pemberdayaan masyarakat sekitar hutan TNB. LSM mampu menggerakkan masa melaui jejaring kerja mereka apabila terdapat pengelolaan pemanfaatan jasa ekosistem TNB yang tidak sesuai dengan ketentuan (organization power).

Kuadran IV disebut sebagai Crowd adalah stakeholder yang memiliki tingkat kepentingan dan pengaruh yang rendah sehingga hanya perlu dimonitor dengan prioritas rendah atau bisa juga diabaikan (Groenendijk 2003). Stakeholder yang termasuk sebagai crowd, yaitu koperasi pegawi TNB. Koperasi pegawai TNB mempunyai kepentingan yang rendah terhadap jasa ekosistem TNB, yaitu hanya berupa kepentingan terhadap fungsi pengaturan sistem penyangga kehidupan dan fungsi habitat. Hal ini dikarenakan anggota koperasi pegawai ini tinggal di sekitar kawasan hutan ketika jam kerja saja, sedangkan tempat tinggal mereka setiap harinya jauh dari kawasan hutan TNB.

\section{Interaksi Stakeholder}

Interaksi antar stakeholders selalu mengandung makna mempengaruhi dan/atau dipengaruhi, dapat berwujud kerjasama ataupun konflik (Reed et al. 2009). Kerjasama antar stakeholders dalam pengelolaan pemanfaatan jasa ekosistem TNB yang sudah berjalan dijabarkan sesuai tingkat perkembanganya mengacu penggolongan Frey et al. (2006), yaitu: koeksistensi, komunikasi, 
kooperasi, koordinasi, koalisi, kolaborasi, dan koadunasi, dengan penjelasan sebagai berikut:

1. Koeksistensi : Keduanya ada tetapi tidak ada komunikasi.

2. Komunikasi : Menyadari keberadaanya, peran tidak pasti, sedikit komunikasi dan semua keputusan dibuat secara sendirisendiri.

3. Kooperasi : Saling memberi informasi, peran sedikit pasti, komunikasi formal dan semua keputusan dibuat secara sendiri-sendiri.

4. Koordinasi : Berbagi informasi dan sumberdaya, peran sudah pasti, sering berkomunikasi dan sebagian keputusan dibuat secara bersama.

5. Koalisi : Berbagi gagasan dan sumberdaya, sering berkomunikasi dan diprioritaskan dan semua anggota mengeluarkan pendapat dalam pengambilan keputusan.

6. Kolaborasi : Para anggota termasuk dalam satu sistem, komunikasi sering dicirikan dengan saling percaya dan konsensus dicapai pada semua keputusan.

7. Koadunasi : Tumbuh bersama

Interaksi antar stakeholder yang sudah berjalan dalam pengelolaan pemanfaatan jasa ekosistem TNB seperti terlihat pada Tabel 17. Hasil penelitian ini menunjukkan bahwa interaksi antar stakeholder dalam rangka kegiatan pengelolaan jasa ekosistem TNB masih belum berjalan dengan optimal. Hal ini disebabkan belum adanya kepastian dari pihak pengelola TNB tentang pengelolaan pemanfaatan jasa ekosistem TNB. Perencanaan (planning) tentang pengelolaan pemanfaatan jasa ekosistem TNB masih belum firm dituangkan dalam dokumen RPTN. Pengorganisasian (Organizing) atau penyusunan kelembagaan pengelolaan pemanfaatan jasa ekosistem TNB masih menjadi kewenangan mutlak pengelola kawasan TNB (sentralistik) dan belum ada pendistribusian hak atau akses. Sehingga pengelola TNB masih bersifat pemegang hak secara penuh (owner).

Hasil penelitian ini menujukkan bahwa interaksi dengan stakeholder dalam rangka pengelolaan pemanfaatan jasa ekosistem TNB masih belum berjalan dengan optimal. Tingkatan interaksi antara TNB dengan stakeholder yang lain masih sebatas pada tingkat koordinasi. Artinya pengelola sudah berbagi informasi dan sumberdaya, peran sudah pasti, sering berkomunikasi, dan sebagian kecil dari 
keputusan pernah dibuat secara bersama (Frey et al. 2006). Sebagian besar interaksi pengelola TNB dengan stakeholder masih sebatas pada tingkat komunikasi, yaitu belum adanya pembagian peran dalam pengelolaan pemanfaatan jasa ekosistem TNB, pertemuan dalam rangka pembahasan pengelolaan pemanfaatan jasa ekosistem belum pernah adan, dan belum pernah duduk bersama dalam rangka membuat keputusan untuk kepentingan bersama.

Tabel 4. Interaksi Stakeholders

\begin{tabular}{lccccccccc}
\hline Stakeholder & $\mathrm{A}$ & $\mathrm{b}$ & $\mathrm{c}$ & $\mathrm{d}$ & $\mathrm{e}$ & $\mathrm{f}$ & $\mathrm{g}$ & $\mathrm{H}$ & $\mathrm{i}$ \\
\hline Taman Nasional Baluran & & 2 & 4 & 2 & 3 & 2 & 1 & 2 & 4 \\
Masyarkat HHBK & 2 & & 1 & 1 & 1 & 3 & 1 & 1 & 1 \\
Masyarakat wisata & 4 & 1 & & 3 & 2 & 3 & 1 & 3 & 1 \\
Pemerintah daerah & 2 & 1 & 3 & & 4 & 3 & 2 & 4 & 1 \\
TNI/POLRI & 2 & 1 & 2 & 4 & & 4 & 2 & 3 & 1 \\
Tokoh agama & 2 & 3 & 3 & 3 & 4 & & 2 & 2 & 1 \\
LSM & 1 & 1 & 1 & 2 & 2 & 2 & & 1 & 1 \\
Jurnalis & 2 & 1 & 3 & 4 & 3 & 2 & 1 & & 1 \\
Koperasi pegawai TNB & 4 & 1 & 1 & 1 & 1 & 1 & 1 & 1 & \\
\hline Kenal
\end{tabular}

Keterangan: (a) TNB, (b) Masyarakat HHBK, (c) Masyarakat wisata, (d) Pemerintah daerah, (e) TNI/POLRI, (f) Tokoh agama, (g) LSM, (h) Jurnalis, (i) Koperasi pegawai TNB.

Pengelola kawasan TNB seharusnya dapat meningkatkan interaksi dengan berbagai stakeholder. Tingkatan interaksi yang dapat menjamin keberlanjutan pengelolaan pemanfaatan jasa ekosistem TNB, yaitu sampai pada kolaborasi bahkan koadunasi. Kesuksesan dalam pengelolaan seumber daya alam secara bersama apabila masing-masing stakeholder mampu berinteraksi satu sama lainnya hingga mencapai tingkat koadunasi (Frey et al. 2006).

\section{KESIMPULAN}

Pengelolaan pemanfaatan jasa ekosistem TNB masih belum berjalan dengan baik dan belum sesuai dengan peraturan perundang-undangan yang berlaku. Interaksi dengan berbagai stakeholder belum maksimal sehingga perlu pendekatan model pengelolaan pemanfaatan jasa ekosistem berupa manajemen kolaborasi (co-management) pengelolaan pemanfaatan jasa ekosistem TNB sebagai solusi kedepannya. 


\section{DAFTAR PUSTAKA}

[Balai TNB] Balai Taman Nasional Baluran. 2014. Identifikasi dan Pemetaan Sebaran HHBK dan Pemanfaatannya oleh Masyarakat di Taman Nasional Baluran. Situbondo: Balai TNB.

De Groot RS, Wilson MA, Bournans RMJ. 2002. A typology for the classification, description and valuation of ecosystem functions, goods and services. J Ecological Economics. 4(1):393-408.

Freeman, R. E. 1984. Strategic Management. A Stakeholder Approach. University of Minnesota. Massachusetts. Pitman Publishing Inc.

Frey BB, Lohmeier JH, Lee SW, Tollefson N. 2006. Measuring collaboration among grant partners. American Journal of Evaluation 27(3):383392.doi:10.1177/1098214006290356.

Groenendijk L. 2003. Planning and Management Tools. Enschede (NL): The International Institute for Geo-Information Science and Earth Observation (ITC).

Kusumedi, P dan Bisjoe, A.R.H. (2010). Analisis Stakeholder dan Kebijakan Pembangunan KPH Model Maros di Propinsi Sulawesi Selatan. Jurnal Analisis Kebijakan Kehutanan, 7(3), 179-193.

Nopiansyah F, Basuni S, Purwanto Y, Kosmaryandi N. 2016. Forest resource utilization by the Siberut community and its implications for the Siberut Island Biosphere Reserve policy. Jurnal Manajemen Hutan Tropika. 22(2):94-104.

Reed MS, Graves A, Dandy N, Posthumus H, Huback K, Morris J, Prell CH, Quin $\mathrm{CH}$, Stringer LC. 2009. Who"s in and why? A typology of stakeholder analysis methods for natural resources management. J Enviromental Management. 30:1-17.doi:10.1016/j.jenvman.2009.01.001.

Roslinda E, Darusman D, Suharjito D, Nurrochmat DR. 2012. Analisis pemangku kepentingan dalam pengelolaan Taman Nasional Danau Sentarum Kabupaten Kapuas Hulu, Kalimantan Barat. JMHT. 18(2):78-85. doi:10.7226/jtfm.18.2.78.

Soekmadi R. 2002. National Park Management in Indonesia: Foucused on The Issues of Decentralization and Local People [disertasi]. Gottingen: Faculty of Forestry Science and Forest Ecology, Georg-August University of Gottingen. 